\title{
Democratic Politics in Times of Austerity: The Limits of Forced Reform in Greece
}

\author{
Harris Mylonas
}

From Stagnation to Forced Adjustment: Reforms in Greece, 1974-2010. Edited by Stathis Kalyvas, George Pagoulatos, and Haridimos Tsoukas. London: C. Hurst \& Co, 2012. 320p. \$27.91 paper.

ए ew people have been shielded from the recent financial crisis and fewer still have suffered more than the Greeks. With unemployment rates above 27 percent, youth unemployment just below 60 percent, 25 percent shrinking of the GDP since 2009, higher taxes, lower wages and pensions, and only modest price deflation in the market, it is hard to be optimistic about a quick economic recovery. From Stagnation to Forced Adjustment provides a thorough discussion of the chronic pathologies that rendered Greece the weakest link during the Eurozone crisis. The book's contributors consider a range of explanations for "reform stagnation" in Greece despite the presence of seemingly favorable institutional conditions since the transition to democracy in 1974-a unitary state with stable one-party governments, cohesive parties, and few veto players. The theme of the volume is that lack of reform is causally related to the intense financial crisis that led to the sovereign debt crisis in Greece. The authors suggest that the crisis occured because of contextual factors that did not allow reforms to function properly or in some cases to be implemented at all. By setting the current crisis in a broader historical and political context, the book makes possible a deeper understanding of the developments surrounding it. And a review of this book provides an opportunity to also consider the broader meaning of the

Harris Mylonas is Assistant Professor of Political Science and International Affairs at George Washington University's Elliott School of International Affairs (mylonas@gwu.edu). He is the author of The Politics of Nation-Building: Making Co-Nationals, Refugees, and Minorities (Cambridge University Press, 2013). He is currently working on a book project - tentatively entitled Varieties of Diaspora Managementanalyzing why some states develop policies to cultivate links with andlor to attract back some of their co-ethnics abroad but not others.
Greek crisis, which poses important questions for the future of democracy in the Eurozone.

The volume is divided into three sections. The first part includes various theoretical accounts that attempt to explain the paradox of reform stagnation in Greece. The second part offers specialized treatments of the most imporant sectors: market reforms, pension system, public health, education, administrative system, and foreign policy. The third section of the book focuses on the onset of the crisis and provides an account of the forced reforms that were imposed as a result of the Memorandum of Understanding signed between the European Union-European Cental Bank-IMF (a.k.a 'troika') and the Greek government.

In the theoretical section, Dimitris Sotiropoulos suggests different ways that a reform can fail and then explores the causes of reform failure in Greece in particular. He primarily focuses on failure following the adoption of a reform and concludes that while common explanations focus on political cost, financial constraints, or party competition alone, we need also to take into account historical legacies that constrain reform. Such legacies include: placing reform priorities in defense rather than other more dynamic sectors; polarized party competition; biased state intervention in society in favor of powerful interest groups; and weak capacity in Greek public administration.

Kevin Featherstone and Dimitris Papadimitriou survey the literatures on neo-corporatism, varieties of capitalism, welfare regimes, and Europeanization, and attempt a synthesis that would best describe the Greek or Southern European variety more generally. They maintain that "the path to the Greek sovereign debt crisis was clearly marked by the domestic impediments to reform" (46). Vassilis Monastiriotis and Andreas Antoniades go beyond dominant grand narratives just cited that have been used to account for reform failure in Greece. Instead they focus on the conception and design stage of policy formulation and argue that "in many instances of reform failure 
in Greece, the problem lies with the content rather than the context of reform" (54). Finally, Haridimos Tsoukas takes issue with studies of reform that he calls merely representaitonal, and suggests that we should focus on how reforms are enacted, "focusing on meaning, context and time" (67). He invites us to consider the embeddedness of the reform into a broader institutional field rather than to focus on point predictions of "outcome explanations" (80-81).

The specialized chapters that make up the middle section of the volume are particularly strong. Former Greek Minister for Economy and Finance, Nikos Christodoulakis, narrates the successive attempts of center-right and center-left governments since 1990 to implement market reforms, illuminating the deficiencies in the "technology of reform" but also the problems involved with "third order change" that Haridimos Tsoukas identified in his chapter. Similarly, Platon Tinios, Manos Matsaganis, Apostolos Dimitropoulos, and Calliope Spanou unpack the rigidities experienced in pension, public health, education, and administrative reform, respectively.

The third and final section is dedicated to the 2010 Greek economic crisis and the political economy of forced reforms that followed the loan agreement. Michael Mitsopoulos and Theodore Pelagidis provide an interpretation of the crisis and the conditionality program, describing the Greek economic and political model as "an uncompetitive conundrum of excessive, rigid and vague regulations that distributed rents to well organized interest groups and created a fertile breeding ground for corruption and abuse of office and public money" (211). They also focus on the evolution of public finances as a catalyst for the 2010 crisis, assigning the blame to consecutive governments that did not manage to control primary expenditures as well as reduce tax evasion and the shadow economy. These failures became apparent when GDP growth slowed down significantly during 2009.

To be sure, beyond the domestic factors, the broader European and global context also played an important role in causing the Greek crisis. For one, the Eurozone was far from what economists decsribed as an optimum currency area; ${ }^{1}$ moreover, the European elites did not take the necessary measures to address these shortcomings of the Euro-e.g., no fiscal solidarity system was put in place —and failed to enforce the 3 percent deficit-to-GDP and 60 percent debt-to-GDP ratios across the EU member states that were stipulated in the Stability and Growth Pact signed in the late 1990s. George Pagoulatos's concluding chapter on "the political economy of forced adjustment" focuses on these factors. Pagoulatos highlights the disjunction between the severity of the fiscal problems confronting the Greek government and the weaknesses of Greek political elites, who were not bold enough or even ready to negotiate; who chose to sideline their own policy experts; and who sought to implement the forced adjustment program in the most short-sighted way possible, beginning with tax increases and wage and pension cuts rather than with structural reforms (a point also emphasized by Michael Mitsopoulos and Theodore Pelagides). The chapter neatly applies theories of institutional change and reform to the Greek case, making clear that the government, with few Ministers as exceptions, did not take ownership of the adjustment program and that a "core executive" emerged-i.e., the minister of finance-thus assuming a tremendous and unprecedented degree of power vis-à-vis the parliament and the rest of the ministers. These developments, although celebrated in this volume as necessary to cut the Gordian knot of "reform stagnation," did not come without huge political costs. In fact, in what follows I make the case that "forced adjustment" and the way it was managed by political elites led to the most important reconfiguration of the Greek political system since its transition to democracy in 1974

In the time since the book manuscript was completed in 2011, the Greek political landscape has changed tremendously. Arguably the political situation is more volatile than at any time since the junta fell 40 years ago. Moreover, since 2011 the financial debt crisis afflicting Greece has spread to other vulnerable European economies such as Ireland, Portugal, Spain, and Cyprus. In all cases, their democratically-elected governments no longer had the ability, due to their participation in the Eurozone, to either devalue their currency or inflate their economies by printing more money. Under international capital mobility, governments with fixed exchange rates confront a trade-off between external currency stability and domestic monetary policy autonomy. ${ }^{2}$ Instead, they were faced with two suboptimal options: to default or to implement austerity measures (internal devaluation). ${ }^{3}$ The European Central Bank-with the consent of German Chancellor Angela Merkel and then-French President Nicolas Sarkozy, decided to stick to a monetary policy that would punish the countries that failed to converge in terms of competitiveness and fiscal balances, rather than hurt French and German banks and risk further contagion. These developments have since given rise to Euroscepticism throughout the EU, leading to a growing public dissatisfaction in the crisis-stricken countries with their own governments but also with the European Commission and the European Central Bank, and reminding everyone of the democratic deficit problem that has long existed within the European Union-i.e., that non-elected institutions have so much power over democraticallyelected governments. ${ }^{4}$

More importantly, the quality of democracy within these EU member states has deteriorated as well, reminding many of Seymour Martin Lipset's 1959 essay on the "social requisites of democracy." Others have drawn the analogy between the political situation in parts of Europe today and European politics during the Great Depression in the 1930s. ${ }^{6}$ 
The levels of unemployment have dramatically increased and trust in government and EU institutions has plummeted. Both Greece and Italy ended up with technocratic governments in the middle of the crisis, something seen by many observers as a blow to democratic legitimacy. ${ }^{7}$ Notwithstanding these developments, Ireland, Portugal, Spain, Cyprus, and even Italy did not experience as drastic a reconfiguration of their sociopolitical system as did the Greek system.

In what follows I outline this dramatic reconfiguration and consider its implications for Greece and for Europe. First I trace the party system transformation, cleavage structure reconfigurations, and the intensification of social discontent in crisis-stricken Greece. Next, I focus on the chronic pathologies in Greek state-parties-society relations that have turned it into the weakest link in the Eurozone. Greece's experience may have been unique but it is inseparable from broader developments in the European and global commons. ${ }^{8}$ Despite the special characteristics of the Greek case, I conclude that looking deeper into the political and economic travails of Greece can improve our understanding of the tension between democratic governance and the demands imposed on national economies by the $\mathrm{EU}$ institutions, as well as by key actors in the world of finance more generally. In fact, the Greek case parallels the experience of other regions like Latin America, where the financialization of national economies catalyzed tensions between international creditors and debtor governments, who seek to adhere to market calls for economic stability but without fanning social instability.

The Greek case merits further specialized study since it most clearly illustrates the challenges of democratic politics in times of austerity and may serve as a window to the future of other European polities. In Greece, new discourses on the role of populism, nationalism, and violence in politics have re-emerged in disturbingly polarized ways. But the rise of right-wing extremism and the consequent challenges to multiculturalism coupled with the ambivalence concerning the future of the European project are not just Greek problems. They can be found in many corners of Europe, and thus ought to be of concern to all who care about the future of Europe.

\section{Mapping the Greek Crisis}

\section{The Transformation of the Party System}

It has been over thirty years since the Panhellenic Socialist Movement (PASOK) took power for the first time in the historic October 18, 1981 election. ${ }^{10}$ In Adam Przeworski and Fernando Limongi's terms, this first "post-junta" smooth transfer of power sealed the democratic transition in Greece. ${ }^{11}$ After experiencing what Giovanni Sartori has called a polarized and fragmented party system in the second half of the 1970s, ${ }^{12}$ Greece became effectively a two-party system with center-left PASOK and center-right Nea
Demokratia (ND) sharing over 80 percent of the 300 seats in the Parliament for the next three decades. Next to these two parties, the Communist Party of Greece (KKE) —along with some other small parties—gained a significantly smaller number of seats. ${ }^{13}$ The $1989-90$ period of instability, polarization, and unorthodox coalition governments between the left and the right did not actually change the structure of the party system in any lasting way. Thus, we can safely say that the first serious shift in Greece's party system in the "post-junta" period occurred in the summer of 2012.

The system that crystalized by the late 1970s was irreversibly shattered in both the May and June 2012 elections. PASOK and ND, the two poles of that two-party system, jointly received a mere 32 percent of the vote in the May 2012 election. The decades-old rivals, PASOK and $\mathrm{ND}$, now governed together. A left-wing party, Coalition of the Radical Left (SYRIZA), which received only 4.9 percent of the vote in the 2009 election, received 26.9 percent in the June 2012 election and has become a serious contender for coming first in the elections to the European Parliament in May 2014. The once all-powerful PASOK went from 44 percent in the 2009 election to a mere 12 percent in the June 2012 elections and now polls at 6.3 percentparticipating in the May 2014 elections to the European Parliament as part of a broader alliance, "Olive TreeDemocratic Alignment." ${ }^{14}$ At the same time, Golden Dawn, one of the most extreme right-wing parties in Europe, increased its strength from 0.29 percent in the 2009 to 7 percent in 2012 elections. ${ }^{15}$ New political parties have been established - and some of them have already been dissolved — and public opinion is especially volatile. It is indicative that a new party, The River, is polling at over 10 percent just two months after its establishment! The political personnel has been significantly renewed, since the dominant parties connected with the crumbling patronage contract-the "social contract" between the cartel parties and the client/voters - have elected far fewer MPs. ${ }^{16}$ Finally, when the Greek public was recently asked whether they trust political parties, government, and parliament, the response was a pretty resounding "no," as these institutions received favorable responses from 4, 9, and 10 percent, respectively. ${ }^{17}$

\section{Cleavage Reconfiguration}

The transition to democracy in 1974 produced important cleavage reconfigurations at the national level. ${ }^{18}$ The populist establishment/anti-establishment cleavagebetween a "non-privileged" majority and a minute privileged "oligarchy" representing foreign and domestic "monopolies"-initiated by Andreas Papandreou in the mid-1970s captured the imagination of most Greeks for most of the 1980s. The most characteristic slogan from this period is "PASOK in government, the People in power." The 1990s saw an ultimately unsuccessful attempt 
to promote technocratic governance and modernization against practices of vested interests and populism. During this period ideological differences between the two dominant parties diminished.

And then the financial crisis hit, resulting in the signing of a memorandum of agreement with Greece's lenders as a condition for bailout loans. Since 2010, the country has been divided along a memorandum/anti-memorandum cleavage. ${ }^{19}$ The specific positions of each party have differed, but we can safely say that political parties are divided between those that see the memorandum as the way out of this crisis and those that oppose the reforms and austerity measures and suggest that Greece's debt is illegitimate and cannot realistically be repaid. In the latter camp, some go as far as wanting to exit the Eurozone and, in the case of the Communist party, even the EU.

What is even more disorienting is that this cleavage cuts across the traditional left/right cleavage. In the pro-memorandum camp we find the two ideological archenemies of the post-junta period, ND and PASOK, and, at least until the summer of 2013, the Democratic Left (DIMAR - a split-off from SYRIZA). The River also appears to be on this side of the divide. The situation is no less ideologically diverse in the anti-memorandum camp. Here we find the main opposition party, the Coalition of the Radical Left (SYRIZA), the Communist Party of Greece (KKE), together with the right-wing Independent Hellenes, and the neo-fascist party, the Golden Dawn. ${ }^{20}$

Volatility in the electorate has been amply demonstrated in analyses of polls, but is also apparent in the Parliament. After decades of ironclad party discipline, since 2009 Greek parties have experienced multiple resignations and expulsions of MPs from parliamentary groups precipitated by contested votes over controversial austerity measures that flowed from the loan agreements with the troika. ${ }^{21}$ There was even a point in time in the past four years when, as a result of resignations and expulsions, independent MPs were the second largest group in the Parliament with 65 legislators. This trend has undermined the predictability of votes in the Parliament. ${ }^{22}$

\section{Intensification of Political Violence}

Political violence is not a new phenomenon in Greece. It suffices to recall the Revolutionary Organization 17 November, a notorious Marxist urban terrorist organization that operated for over two decades, assassinating 23 people in 103 attacks. $^{23}$ Since December 2008, however, quantitative and qualitative changes in the ontology of political violence have taken place. The December 2008 riots were the first expression of the latent frustration and resentment of the Greek youth toward the Greek state. Andreas Kalyvas recently described the intensity, large size, spontaneous organization, and anti-state character of the riots. ${ }^{24}$ According to Kalyvas, "an insurrection occurred in Greece last December [2008]; a rebellion against state authority and its constitutional order by a part of its population." 25 These events took place long before Greece entered the loan agreement with the troika. In the wake of the agreement, the insurrectionist impulse was exacerbated by political animus against the austerity measures, the troika, and what was understood by the protesters to be a foreign political elite. During parliamentary sessions to debate and vote on the successive rounds of austerity measures, events took a troubling, violent turn. Following the first loan agreement between the Greek government and the troika on May 5, 2010 and during one of the largest protests in recent years, violence culminated in the arson of the Marfin Bank building, resulting in the entrapment and death of three employees. In late June 2011 "138 police officers were injured, more than 500 protesters were hospitalized with breathing problems caused by the use of tear gas by the police, Syntagma metro station resembled a wartime hospital, tens of protesters were wounded, while 46 demonstrators were taken to police stations and 11 of them arrested on June 29, 2011 alone."26 In February 2012, the vote on another battery of austerity measures took place while forty buildings were burning across Athens and thousands were protesting outside the parliament. Next to these events, smaller scale violent confrontations with the police have repeatedly occurred whenever the particular vested interests discussed by George Pagoulatos, Platon Tinios, and Manos Matsaganispublic sector workers, truck drivers, taxi owners, port workers, and farmers - have been challenged by attempts to implement troika-mandated structural reforms.

This political violence has indeed become both pervasive and increasingly linked to organized terrorist campaigns. One new radical anarchist group, "Nuclei of Fire," has been successfully dismantled by police, though its terrorist hits have apparently continued. More worrisome, Christodoulos Xiros, one of the leaders of the Revolutionary Organization 17 November, disappeared early in 2014 while on a holiday prison furlough and issued threats of major armed attacks against the Greek government in a video circulated on the web. ${ }^{27}$

On the right, Golden Dawn has repeatedly attacked immigrants and fought with left-wing groups ranging from antifascists to communists and anarchists. This violent behavior culminated in the murder of Pavlos Fyssas-a Communist Party sympathizer and anti-fasist musicianby a party cadre in what the High Court of Greece described as a coordinated hit implicating the whole hierarchy of the Party. ${ }^{28}$ Less than two months later, Golden Dawn members Manos Kapelonis and Giorgos Fountoulis were murdered by a new terrorist organization called "Militant Popular Revolutionary Forces." In their proclamation assuming responsibility for the hit, the new organization argued that these were political executions in retribution for the killing of Pavlos Fyssas and "the starting point of a popular campaign to send the neo-Nazi scum of Golden 
Dawn where they belong, to the trash can of history." 29 These killings set off a debate over the role of violence and whether any other form of violence-besides state violence_can be seen as legitimate. I will return to this in the concluding section.

\section{Chronic Pathologies: The "Patronage Contract"}

In his seminal work on The Breakdown of Democratic Regimes, Juan Linz defined a legitimate government as "one considered to be the least evil of the forms of government" and suggested that "democratic legitimacy is based on the belief that for that particular country at that particular historical juncture no other type of regime could assure a more successful pursuit of collective goals." ${ }^{30}$ A system that satisfied these conditions was in place in Greece until recently. But it quickly crumbled when the combined economic and political crisis caused growing numbers of the population to feel indefinitely excluded from the system.

The Greek economy is rather weak and dependent on foreign loans, and most citizens have sought the "stability" provided by public-sector employment. Securing such a position, however, has required reliance on nationwide party-dominated patron-client networks. Not surprisingly, political competition has revolved around the control of the exceptionally centralized state administration almost since independence. ${ }^{31}$ This has been the main pillar of party-voter patronage contract.

When it comes to the private sector, a large number of businesses have traditionally been dependent on government contracts, loans, and protection to survive. ${ }^{32}$ In turn, an important sub-group of this private sector provided financial support for the very same parties that allocated these government contracts. Similarly, owners of media outlets - both national and local-competed for party and state advertisements, licenses, and lenience in paying taxes or fines. This party-businesses contract blurred the liberal public-private distinction. ${ }^{33}$

This patronage contract developed during the period when the two main competitors, PASOK and Nea Demokratia, both dominated the political space and colluded to employ the resources of the state to ensure their own collective survival. This is not solely a Greek phenomenon. As Richard Katz and Peter Mair have put it, "political parties increasingly function like cartels, employing the resources of the state to limit political competition and ensure their own electoral success." 34 But in Greece this cartelization took an extreme form. And while this system was initially legitimated as an attempt to consolidate democracy and to prevent the return to military rule, it soon became an end in itself. The parties controlled the state and passed legislation (e.g., state funding of parties, "reinforced" proportional representation, parliamentary immunities, statute of limitations for crimes committed by Ministers, and so forth) that reproduced their dominance. And Greek voters continued to return them to office.

In the past thirty years, Greece has experienced strong electoral cycles of populist spending aptly described in the chapter by Michael Mitsopoulos and Theodore Pelagidis, which have increased deficits and built up an enormous state debt over time. Reforms stagnated as the volume under review amply demonstrates. Starting in the 1980s, EU subsidies were also (ab)used by the cartel parties, generating more perverse incentives in society and exacerbating the pre-existing trend. ${ }^{35}$ Traditional clientelism, primarily practiced by the dominant right up until 1981, was transformed by PASOK and Andreas Papandreou into what George Th. Mavrogordatos has called "machine politics." The main difference between the two systems is that in the latter patronage is channeled through the impersonal party organization rather than individual politicians. ${ }^{36} \mathrm{ND}$ did not take long to follow suit.

Endemic populism from both cartel parties led to the development of myriad vested interests, corrupt practices, an emaciated and largely state-dependent private sector, an inefficient public sector, and a culture of reliance on the state. ${ }^{37}$ This patronage politics generated substantial public debt, which kept resources from being invested in productive activities that could lead to sustainable growth. There were attempts in the 1990s to reverse this trend, but to no avail. Electoral cycles continued and so did tax evasion. ${ }^{38}$ The onset of the most recent global financial crisis caused this already faltering patronage system to crash, leading to its steady delegitimization.

Blocked social mobility for those already in the labor market and marginalization or wholesale exclusion of youth attempting to enter it-especially high school students-produced an explosive mix. The percentage of denizens who felt marginalized or estranged by the current system was growing. As Michael Mitsopoulos and Theodore Pelagides put it, "the deeper failings of the adopted economic model of unconstrained rent creation and distribution in an environment where the rule of law was faltering kept permeating a society whose coherence continued to deteriorate as quality employment, especially for the young, was becoming an impossibility for most Greek families" (212-213). Into this mix was added another overlooked ingredient: immigrants of all juridical categories — asylum seekers, undocumented, resident aliens. Andreas Kalyvas observed that "a new subject [is] appearing into the public realm, the rebellious immigrant, politicized and public, claiming a political life .... [which] expanded the boundaries of the political, enlarged the practice of democratic action, and included those who are otherwise excluded from the commons." 39

By 2008 various groups of the population-especially but not exclusively the youth - thus felt irreversibly excluded from the sociopolitical regime that had developed in postjunta Greece. ${ }^{40}$ 


\section{Conclusion: Democratic Legitimacy in Times of Crisis}

As From Stagnation to Forced Adjustment makes aboundantly clear, the political context and the discourse employed by its principal actors shapes both the content of reform but also the likelihood of its success. The post-junta period was not without important success stories. Greece experienced a long period of peace and democratic governance, it overcame the deep divisions going back to the Greek Civil War, it joined the European Union, and for a long period of time enjoyed economic prosperity. And yet today all of these achievements are in jeopardy.

The political challenges associated with "forced adjustment" cast a dark shadow over Greek (and European) political discourse. The Greek memorandum/anti-memorandum cleavage is very much a result of the way the crisis was managed by succesive governments and by the troika. ${ }^{41}$ This cleavage has recently come under fire by Prime Minister Antonis Samaras, who is attempting to establish another, more favorable cleavage, between the adherents of stable democratic rule of law and those that condone anti-systemic violent acts. Through this move Samaras is attempting to put Golden Dawn, anarchists, and at least parts of SYRIZA - the main opposition party-in the same camp, casting them as the "two extremes" and contending, against both, that there is no justification for violence. SYRIZA is trying to avoid this cleavage reconfiguration, characterizing Samaras's attempt as a diversionary strategy designed to draw attention away from the government's persistence in blindly following what they see as an externally enforced and catastrophic mix of neoliberal policies.

In the face of the inability of political elites to replace the crumbling patronage contract with a new type of social contract, increasing numbers of Greeks harken back to identities that preexist and in some cases even call into question the post-junta democratic transition. These issues include the Greek national identity-an amalgam of ancient Greek heritage and Christian Orthodoxy, but not necessarily the Church; divergent narratives of the Greek Civil War; the 1967 coup; and the accession to the European Union. Contemporary Greek public life is increasingly divided between two large blocs that take very different and indeed antagonistic positions on these issues.

One bloc celebrates the Civil War defeat of the left, regards the junta as a much-maligned period of underappreciated stability, ${ }^{42}$ and is hostile to the idea of immigrants-especially those who are non-Greek-speaking and non-Orthodox-permanently residing in Greece or becoming Greek citizens. The other bloc consists of people who are critical of the role of the West in the Greek Civil War, consider the junta one of the darkest moments in modern Greek history, are open to the idea of Greece becoming a more diverse society, and can embrace the idea of Greek citizens who are not of Greek origin. The opposition between these two blocs is cross-cut by the two dominant political cleavages outlined above, the democratic rule of law versus anti-systemic violence cleavage advanced by Prime Minister Samaras, and the memorandum versus anti-memorandum cleavage pushed by SYRIZA. Both blocs have their small violent factions. Moreover, both blocs have pro- and anti-memorandum constituencies. How these divisions get worked out, and whether they will be resolved in a manner that is consistent with the rule of law, democratic legitimacy, and a return to social stability, are central questions looming before Greece.

From Stagnation to Forced Adjustment: Reforms in Greece, 1974-2010 illuminates the political-economic sources of the current Greek crisis. Some of its chapters directly engage the politics of forced adjustment as a result of the financial crisis. The volume, however, was written before the financial crisis was transformed into an economic recession and unemployment crisis. Once the multiple pathologies described in the volume's chapters were violently attacked by the forced reforms imposed by the creditors, then the limits of this process became apparent. The political system collapsed. ${ }^{43}$

Pagoulatos rightly suggests that "even externallyinduced, forced adjustment, even reform whose time has come, needs a public legitimizing discourse" (265). The contemporary political discourse in Greece, however, indicates that instead of a "reformist agenda," which has a marginal appeal, the options oscilate between a return to "traditional" forms of authority, whether right or left, or a new patronage contract-assuming that the latter is even financially possible. This means a drift away from the European project, as Greek elites representing the "traditional" options lean towards national sovereignty rather than further European integration.

Greece thus confronts a double crisis of democratic legitimacy. On the one hand it wrestles with deep and protracted political antagonisms that are exacerbated by an economic decline made even more severe by the politics of forced adjustment. On the other hand it wrestles with the question of its place in Europe, and whether and how it can create a new social contract while also functioning in a regional economy and being fiscally accountable to its troika creditors, investors, and superintendants. Greece confronts these challenges in a particularly serious form. But it is hardly alone, as similar narratives unfold throughout Europe, from Ireland to Spain and Italy to Romania, Hungary, and Bulgaria.

What, then, is the future of national democratic governance within the context of the European Union? Eurozone countries in crisis experience serious pressure from Brussels and Frankfurt, and their populations experienced a lack of alternatives and a serious deficit of democratic agency. How can democratic legitimacy 
re-emerge in the crisis-ridden member states of the EU? Some important intellectuals and political leaders propose further democratic legitimation of $\mathrm{EU}$ institutions through changes that would turn more of them into elected bodies that are accountable to voters. Others advocate a more fully intergrated European Union, centered on a program of solidaristic fiscal transfers-which would of course require further political integration, something rather unlikely in this juncture. The results of the May 2014 elections to the European Parliament will be crucial in this respect. Regardless, the road ahead for Greece and for Europe is a long one. Whether there is a democratic path beyond the Eurozone crisis is an open question of enormous importance, both for the future of Europe and for the future of thinking about democratic politics and supranational governance.

\section{Notes}

1 Frieden 1998, Feldstein 2011, Mundell 1961.

2 Mundell 1960; Broz and Frieden 2001.

3 Matthijs 2014, 103; Blyth 2013.

4 Serricchio, Tsakatika, and Quaglia 2013; Torreblanca and Leonard 2013. For a discussion of the situation in Spain, see Miley 2013. For a recent treatment of the issue of legitimacy in the EU, see Schmidt 2013.

5 Lipset 1959.

6 Most recently Matthijs 2014,113.

7 Macartney 2013, 67; Schmidt 2012.

8 For more, see Balibar 2002.

9 For more, see Stephen Kaplan 2013.

10 As George Mavrogordatos pointed out thirty years ago, this event "ended several decades of practically uninterrupted conservative rule and has brought power to the most radical government the country has seen in more than half-a-century, if not since its independence in 1830"; 1983, 3.

11 Przeworski and Limongi 1977.

12 Sartori 1976.

13 See Lyrintzis 2005, Nicolacopoulos 2005.

14 MRB, May 2014. All of the polling results in this section are coming from this survey.

15 The leadership and some followers of the same party are currently under investigation by the highest court in Greece for having formed "a criminal organization" its political leader was imprisoned along with several other of its MPs and followers- that included police officers; the rest of the political parties in Parliament voted to lift the immunity of several of its MPs; and a large majority voted to freeze Golden Dawn's state funding.

16 Moreover, as a survival strategy and in an effort to demonstrate that they received the electorate's message, PASOK and ND attempted to renew their ranks with many new candidates but to no avail.

17 Standard Eurobarometer 79/Spring 2013. See questions: QA12.1, QA12.2, QA12.3.
18 Local cleavages have also existed in Greek politics, including the refugees versus natives cleavage in various parts of the country where refugees settled as well as various other local level divisions along linguistic or other ethnic lines. These, however, were subsumed under the national cleavages that I am describing. For more on cleavage structures, see Lipset and Rokkan 1967.

19 Mavrogordatos and Mylonas 2011, 986.

20 It is worth mentioning that the two main opponents along this cleavage, center right ND and left-wing SYRIZA, have not been consistent in their positions. Prime Minister Samaras, head of ND, opposed the first memorandum in 2010 - while still in opposition-but has become the leading voice in the pro-memorandum camp since he took office in June 2013. Alexis Tsipras has kept his anti-memorandum positions constant but has toned down his rhetoric. For more, see Georgakellos and Mylonas 2013.

21 Just on the February 12, 2012 austerity measures vote to secure the second bailout plan, forty-five MPs were expelled from their parties (PASOK, ND, and the Popular Orthodox Rally-LAOS).

22 To illustrate the degree of the volatility it suffices to mention that an MP moved from ND on the centerright, to LAOS on the right, to Democratic Alliance on the center. This serves as yet another proof that the memorandum/anti-memorandum cleavage is dominant since the moves across parties follow this cleavage and-in some cases-are even endogenous to it.

23 Kassimeris 2004.

24 For a detailed analysis of the events that were sparked by "the senseless shooting of a fifteen-year-old, Alexis Grigoropoulos, by a patrolling police guard at a congested district in central Athens" see Kalyvas 2010.

25 Ibid., 355.

26 Mylonas 2011b.

27 Smith 2014.

28 Multiple MPs of the Golden Dawn have been arrested since then.

29 Kitsantonis 2013.

30 Linz 1978: 18.

31 Tsoucalas 1986; Sotiropoulos 1993.

32 Mitsopoulos and Pelagidis 2012.

33 Tsoucalas 2013.

34 Katz and Mair 2009, 753.

$35 \mathrm{EU}$ development as well as cohesion funds that were supposed to promote e-government, the creation of a land registry, improvement of public sector services, vocational training, modernization of the agricultural sector, and so forth were instead continually mismanaged and ended up in bank accounts of various cronies of the dominant parties. Parallels can also be found in many European societies and especially in the rest of Southern Europe.

36 Mavrogordatos 1997. Lyrintzis 1984 called it "bureaucratic clientelism." 
37 For populism in the 1980s and beyond see Lyrintzis 1987, Mavrogordatos1993, Pappas and Assimakopoulou 2013. Pappas 2014 calls this system "populist democracy," which he defines as a pluralist system in which the government and the main opposition parties behave as populists.

38 As I have argued elsewhere, while Greek public spending and debt crept up, government revenue fell or remained constant in the years after Greece adopted the euro. Between 2001 and 2007 Greece's average government revenues totaled 39.4 percent of GDP, whereas the EU average was 44.4 percent; Liaras and Mylonas 2011.

39 Kalyvas 2010, 356, 359.

40 It is in this light that we can make sense of the observed volatility among both political elites and voters. It is also only through this understanding that we can comprehend the meteoric rise of three very different but anti-memorandum and least systemic partiesSYRIZA, Independent Hellenes, and Golden Dawnsince the voters were trying to vote against the systemic parties that betrayed them by breaking the contract or no longer having the resources to maintain it.

41 It is a fact that the slow response from European political leaders - including the Greek government_and the rather vengeful mix of policy originally decided by the "troika" definitely exacerbated the situation. For more see Mylonas 2011.

42 The 1967 coup and its legacy are very much still with us today. Golden Dawn's sudden rise can be understood through the expression of repressed sentiments of the sympathizers and collaborators of the Greek Junta (1967-1974). Another, way that the junta period is still with us is apparent in slogans of political parties. On the radical left, a common slogan is "Bread, education, freedom. Junta did not end in '73," implying that the current situation since 2009 is another form of junta. On the extreme right, Golden Dawn sympathizers chanted a significantly different version of the slogan: "Bread, education, freedom. Your Junta began in '73."

43 Takis Pappas makes a similar point when he writes that

the current financial and economic crisis has led to the demolition of the two mechanisms that, for decades, had supported Greece's populist democracy. On the one hand, the Greek state, now short of external funds and with its creditors hounding it to apply harsh austerity measures, no longer has rents to hand out to society. On the other hand, the two-party system that was vital to the orderly distribution of rents lies shattered and, for the time being at least, has given way to an extremely polarized form of multipartism;

Pappas 2013, 43.

\section{References}

Balibar, Etienne. 2002. Politics and the Other Scene. Trans. Christine Jones, James Swenson, and Chris Turner. London and New York: Verso.
Blyth, Mark. 2013. "The Austerity Delusion: Why a Bad Idea Won Over the West." Foreign Affairs 92(3): 41-56.

Broz, J. Lawrence, and Jeffry A. Frieden. 2001.

"The Political Economy of International Monetary

Relations." Annual Review of Political Science 4: 317-43.

Feldstein, Martin. 2011. "The Failure of the Euro."

Foreign Affairs, December 13.

Frieden, Jeffrey. 1998. “The Euro: Who Wins? Who Loses?” Foreign Policy 112: 24-40.

Georgakellos, Akis, and Harris Mylonas. 2013.

"Sand Dunes in the Greek Landscape: Party Politics and Political Coalitions in Times of Crisis." The Monkey

Cage (blog), The Washington Post, June 11. (http:// themonkeycage.org/2013/06/11/), accessed March 5, 2014.

Kalyvas, Andreas. 2010. "An Anomaly? Some Reflections on the Greek December 2008." Constellations 17(2): 351-65.

Kaplan, Stephen B. 2013. Globalization and Austerity Politics in Latin America. Cambridge University Press.

Kassimeris, George. 2004. "Fighting for Revolution? The Life and Death of Greece's Revolutionary Organization 17 November 1975-2002." Journal of Southern Europe and the Balkans 6(3): 259-73.

Katz, Richard S., and Peter Mair. 2009. "The Cartel Party Thesis: A Restatement." Perspectives on Politics 7(4): 753-66.

Kitsantonis, Niki. 2013. "Guerrilla Group Says It Killed 2 From a Greek Extremist Party in an Athens Suburb." New York Times, November 18.

Liaras, Evan, and Harris Mylonas. 2011. "What Really Went Wrong in Greece?” CNN.com, November 20.

Linz, Juan José. 1978. The Breakdown of Democratic Regimes: Crisis, Breakdown, \& Reequilibration. Baltimore, MD: Johns Hopkins University Press.

Lipset, Seymour Martin. 1959. "Some Social Requisites of Democracy: Economic Development and Political Legitimacy." American Political Science Review 53(1): 69-105.

Lipset, Seymour Martin, and Stein Rokkan, eds. 1967. Party Systems and Voter Alignments: Cross-National Perspectives. New York: Free Press.

Lyrintzis, Christos. 1984. "Political Parties in Post-Junta Greece: A Case of 'Bureaucratic Clientelism'?" West European Politics 7(2): 99-118.

. 1987. "The Power of Populism: The Greek Case." European Journal of Political Research 15(6): 667-86.

2005. "The Changing Party System: Stable Democracy, Contested 'Modernisation." West European Politics 28(2): 242-59.

Macartney, Huw. 2013. The Debt Crisis and European Democratic Legitimacy. Basingstoke, Hampshire: Palgrave Macmillan. 
Matthijs, Matthias. 2014. "Mediterranean Blues: The Crisis in Southern Europe." Journal of Democracy 25(1): 101-15.

Mavrogordatos, George Th. 1983. Rise of the Green Sun. Athens: Ant. N. Sakkoulas.

. 1993. "Civil Society under Populism." In Greece, 1981-89: The populist decade, ed. Richard Clogg, New York: St. Martin's Press. 1997. "From Traditional Clientelism to Machine Politics: The Impact of PASOK Populism in Greece." South European Society and Politics 2(3): 1-26.

Mavrogordatos, George Th., and Harris Mylonas. 2011. "Greece." European Journal of Political Research 50(7-8): 985-90.

Miley, Thomas Jeffrey. 2013. "Crisis of Democratic Representation in Spain?" paper presented at the Conference on "Democratic Representation in Crisis," as part of the La Pietra Dialogues, organized by New York University and the European University Institute (Florence, Italy).

Mitsopoulos, Michael, and Theodore Pelagidis. 2012. Understanding the Crisis in Greece: From Boom to Bust. Basingstoke, Hampshire: Palgrave Macmillan.

Mundell, Robert. 1960. "The monetary dynamics of international adjustment under fixed and flexible exchange rates," Quarterly Journal of Economics, 74(2): 227-257.

. 1961. "A Theory of Optimum Currency Areas"

The American Economic Review, 51(4): 657-665.

Mylonas, Harris. 2011. "Is Greece a Failing Developed State?" In The Konstantinos Karamanlis Institute for Democracy Yearbook 2011: The Global Economic Crisis and the Case of Greece, ed. Konstantina Botsiou and Antonis Klapsis. Berlin: Springer.

2011a. "The End of Peaceful Protest?" Kathimerini, July 5 .

Nicolacopoulos, Ilias. 2005. "Elections and Voters, 1974-2004: Old Cleavages and New Issues." West European Politics 28(2): 260-78.

Pappas, Takis. 2013. "Why Greece Failed?" Journal of Democracy 24(2): 31-45.

2014. "Populist Democracies: Post-Authoritarian Greece and Post-Communist Hungary." Government and Opposition 49(1): 1-23.

Pappas, Takis, and Zena Assimakopoulou. 2013. "Political Entrepreneurship in a Party Patronage Democracy:
Greece.” In Party Patronage and Party Government: Public Appointments and Political Control in European Democracies, eds. P. Kopecký and M. Spirova, Oxford: Oxford University Press.

Przeworski, Adam, and Fernando Limongi. 1997.

"Modernization: Theories and Facts." World Politics 49(2): 155-83.

Sartori, Giovanni. 1976. Parties and Party Systems: A Framework for Analysis, Vol. 1. New York: Cambridge University Press.

Schmidt, Vivien A. 2012. "The Eurozone Crisis and the Challenges for Democracy." In The State of the Union(s): The Eurozone Crisis, Comparative Regional Integration and the EU Model, ed. Joaquín Roy. Miami: Miami-Florida European Union Center/Jean Monnet Chair.

2013. "Democracy and Legitimacy in the European Union Revisited: Input, Output and 'Throughput'.' Political Studies 61: 2-22.

Serricchio, Fabio; Myrto Tsakatika; and Lucia Quaglia. 2013. "Euroscepticism and the Global Financial Crisis." Journal of Common Market Studies 51(1): 51-64.

Smith, Helena. 2014. "Escaped Marxist Guerrilla Christodoulos Xiros Alarms Greece with Pledge to Return to Arms." The Guardian, January 26.

Sotiropoulos, Dimitrios A. 1993. "A Colossus with Feet of Clay: The State in Postauthoritarian Greece." In Greece, the New Europe, and the Changing International Order, ed. Harry J. Psomiades and Stavros B. Thomadakis. New York: Pella.

Standard Eurobarometer 79. 2013. Public Opinion in the European Union, Fieldwork: May 2013. Brussels: European Commission. (http://ec.europa.eu/public_ opinion/archives/eb/eb79/eb79_en.htm), accessed March 5, 2014.

Torreblanca, Jose Ignacio, and Mark Leonard. 2013. "The Continent-Wide Rise of Euroscepticism." European Council on Foreign Relations Policy Memo.

Tsoucalas, Constantine. 1986. Social Development and the State: The Composition of the Public Sphere in Greece. Athens: Themelio.

_. 2013. Morfes Sinehias kai asinehias: Apo tin Istoriki Ethnegersia stin Oikoumeniki Dysforia [Forms of Continuity and Discontinuity: From Historic Restoration to Ecumenical Dysphoria]. Athens: Themelio. 